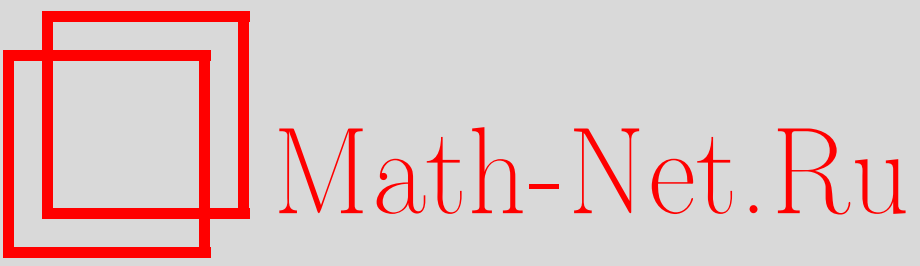

П. Л. Ульянов, Ю. В. Покорный, С. А. Шабров, Воронежская зимняя математическая школа "Современные методы теории функций и смежные проблемы", УМH, 2005, том 60, выпуск 3, 185-186

DOI: https://doi.org/10.4213/rm1439

Использование Общероссийского математического портала Math-Net.Ru подразумевает, что вы прочитали и согласны с пользовательским соглашением

http://www.mathnet.ru/rus/agreement

Параметры загрузки:

IP : 34.229 .45 .116

26 апреля 2023 г., 13:54:43 


\section{ВОРОНЕЖСКАЯ ЗИМНЯЯ МАТЕМАТИЧЕСКАЯ ШКОЛА “СОВРЕМЕННЫЕ МЕТОДЫ ТЕОРИИ ФУНКЦИЙ И СМЕЖНЫЕ ПРОБЛЕМЫ"}

\footnotetext{
Очередная (школш в Воронеже проводятся раз в два года) школа проводилась Воронежским государственным университетом совместно с Московским государственным университетом им. М. В. Ломоносова и Математическим институтом им. В. А. Стеклова Российской академии наук с 27 января по 2 февраля 2005 г. в курортной зоне г. Воронежа.

Основные научные направления программы школы:

- действительньй и комплексный анализ,

- тригонометрические и ортогональные полиномы и ряды,

- аппроксимация функций действительного и комплексного переменного полиномами,

- граничные свойства аналитических функций,

- приближение в функциональных пространствах,

- оптимальное управление,

- спектральная теория дифференциальных операторов,

- современные разделы качественной теории краевых задач,

- смежные проблемы математического моделирования,

- проблемы преподавания математики в высшей и средней школе.
}

Оргкомитет работал в составе: П. Л. Ульянов (Москва) - председатель, И. И. Борисов (Воронеж) - сопредседатель, Ю.В. Покорный (Воронеж) - зам. председателя, А. Д. Баев (Воронеж) - зам. председателя, Б. И. Голубов (Москва), В.Г. Звягин (Воронеж), Б. С. Кашин (Москва), Ю.Ф. Коробейник (Ростов-на-Дону), В.З. Мешков (Воронеж), С. М. Никольский (Москва), В.И. Овчинников (Воронеж), В.В. Провоторов (Воронеж) - ученьй секретарь, Ю.И. Сапронов (Воронеж), Е.М. Семенов (Воронеж), А.М. Седлецкий (Москва), Ю.Н. Субботин (Екатеринбург), А. П. Хромов (Саратов).

В работе школы приняло участие около 120 человек более чем из 30 городов России и зарубежья, в том числе 31 из Москвы, 20 из Воронежа, 8 из Саратова, по 5 из Минска, Самары, по 4 из Белгорода, Орла, Петрозаводска, по 3 из Ижевска, С.-Петербурга, Ставрополя, Ростова-на-Дону, по 2 из Вологды, Долгопрудного, Запорожья, Казани, Махачкалы. Также были представители Алексина, Архангельска, Владикавказа, Владимира, Днепропетровска, Курска, Липецка, Красноярска, Нижнего Новгорода, Пушкино, Новосибирска, Старого Оскола, Твери, Смоленска. Сочли необходимым приехать математики из зарубежья - Запорожья, Минска и Днепропетровска. В числе непосредственных участников - один член-корреспондент РАН, 32 доктора и 33 кандидатов наук. Около 30 аспирантов и студентов. В работе школы приняли участие и учителя школ.

Отрадно существенно более широкое, чем на прошлых школах, участие в конференции молодых ученых (более 40 человек представлявших почти все города). Школа была поддержана Российским фондом фундаментальных исследований, ряд молодых ученых получил персональные гранты для участия в этой школе. По приглашению оргкомитета с лекциями выступили следующие известные ученые:

А. В. Абанин (Ростов-на-Дону) "Преобразования Фурье и Фурье-Лапласа в теории ультрадифференцируемых функций и уштрараспределений”; 
А. П. Хромов (Саратов) "Интегральные операторы с разрьвными ядрами";

П. Л. Ульянов (Москва) “Девяностолетие Лузинской математической школы. История создания";

С.В. Конягин (Москва) "Некоторые вопросы теории обучения и теории приближения";

В. В. Старков (Петрозаводск) "О локально биголоморфных отображениях многосвязных областей";

А. В. Арутюнов (Москва) “Анормальные задачи теории экстремума и нелинейного анализа”;

М. И. Дьяченко (Москва) "Альтернативные классы Ватермана и сходимость кратных рядов Фурье";

П. П. Забрейко (Минск) "Функциональньй анализ и математическая экономика";

В. И. Овчинников (Воронеж) "Теорема вложения для аналогов пространств Орлича";

Е. М. Семенов (Воронеж) "Свойство Банаха-Сакса";

В. И. Данченко (Владимир) "Некоторые задачи о разделении особенностей функций";

Ю.И. Сапронов, А. Ю. Борзаков (Воронеж) "Нелокальный бифуркационньй анализ некоторых краевых задач".

Работали секции, в которых были представлены 30-минутные доклады и 20 минутные сообщения:

секция "Теория функций действительного переменного" - 8 докладов, 17 сообщений;

секция "Теория функций комплексного переменного" - 7 докладов, 16 сообщений;

секция "Качественная и спектральная теория краевых задач, оптимальное управление и математическое моделирование" - 6 докладов, 22 сообщения;

секция "Проблемы преподавания математики в средних и высших учебных заведениях" - 2 доклада и 5 сообщений.

Были проведены два круглых стола, которые вызвали болшшой интерес и оживленные научные дискуссии:

"Математическая модель государства" (под руководством В. К. Захарова, Е. С. Половинкина, А. Д. Яшина);

"Проблемы преподавания математики в высшей и средней школе" (под руководством Ю. В. Покорного).

Для участников конференции организовьвались катание на лыжах, купание в проруби, прогулки по зимнему лесу и оживленные научные дискуссии.

Тезисы были опубликованы к началу работы школы.

По общему мнению участников, школа прошла очень успешно. Неординарньй уровень всех лекций, творческая атмосфера секций, где практически каждый доклад или сообщение инициировали обсуждения и обмен идеями, возможность, отвлекшись от повседневной суеты, поговорить о математических достижениях и перспективах сделали школу ярким, интересным и полезным событием в жизни отечественного математического сообщества.

П. Л. Ульянов, Ю.В. Покорныцй, С.А. Шабров 